\title{
Bybelse teologie - dogmatiese teologie
}

\author{
DJ Smith
}

\section{Abstract}

Biblical theology - dogmatic theology

The purpose of this article is to make a contribution to the discussion between systematic theology and biblical theology from the point of view of what systematic theology can expect of the latter. In this discussion the ideas of JP Gabler, as portrayed by $\mathrm{H}$ Boers, can play an important role. The following notions are identified: Dogmatic tendencies should not play a part in the presentation of a biblical theology. Biblical theology should accept a responsibility only to the biblical material which is employed; form a bridge between the exegesis and the exegetical results on the one hand and the systematic theology on the other hand; keep its purpose aligned to dogmatic theology and help to construct methods as how to incorporate the diversities and unity in the biblical witness.

Die titel van hierdie studiestuk wil iets sê van wat ons met die studiestuk beoog, en hierdie doel kan in twee punte saamgevat word. Eerstens glo ons dat daar 'n gesprek tussen die Dogmatiek en die Bybelwetenskappe, dit wil sê Ou- en Nuwe-Testamentiese Wetenskap, moet plaasvind. Tweedens wil ons die gesprek stimuleer deur vanuit die oogpunt en behoeftes van die Dogmatiek die bydraes van die Bybelse teologie (hieronder verstaan ons die Ou en Nuwe Testament teologie, as onderafdeling van die Bybelwetenskappe), aan te dui wat ons glo tot 'n sinvolle gesprek kan lei. Dit kan verder ook daartoe lei dat die Dogmatiek op 'n nog meer gesonde en wetenskaplik-verantwoorde basis beoefen word. Daar sal ook enkele vrae aan die Bybelse teologie as vakwetenskap gevra word, veral daar waar ek van mening is dat die Bybelse teologie nie 'n saak reg benader ten opsigte van die Dogmatiek, oftewel Sistematiese teologie, nie.

Dit is vir my baie duidelik dat die gesprek tussen die Dogmatiek en die Bybelwetenskappe nie net wenslik is nie, maar ook dat dit noodsaaklik is. Beide kante het iets konstruktief vir mekaar te sê. Tot onlangs toe was daar, myns insiens, 'n te groot verwydering tussen die vakgebiede en was die neiging daar om die eie vakgebied te veel in isolasie te beoefen. Baie dogmatici het hulle daaraan skuldig gemaak om hulle vakgebied as ' $n$ finale afgeronde sisteem te benader en vanuit 'n geslote denkpatroon te beoefen. Die Bybelwetenskappe, en in be- 
sonder die Bybelse teologie, is ook baiekeer in 'n sekere sin geïsoleerd beoefen deurdat eksegete vanuit die geslote kring van die eie vakgebied negatiewe kritiek teenoor die wyse waarop Dogmatiek beoefen word, uitgespreek het en dikwels nie 'n positiewe gerigtheid op die Dogmatiek geopenbaar het deur die nodige bruikbare eie-vakwetenskaplike insigte aan die Dogmatiek deur te gee nie. Ons wil nou ons bydrae tot hierdie gesprek lewer deur sekere sake aan te stip wat ons as dogmatici spesifiek van die Bybelse teologie verwag en miskien ook wat ons as ongewens beskou.

Ons gaan van die standpunt uit dat 'n gesprek tussen die Dogmatiek en die Bybelse teologie nodig is, wel bewus daarvan dat daar in die Bybelwetenskappe geen eenstemmigheid is oor wat ' $n$ Bybelse teologie presies is of behoort te wees nie. Daar gaan selfs stemme op wat vra of dit moontlik is om 'n teologie van die Ou of Nuwe Testament te skryf. 'n Bloot oppervlakkige kennismaking met ouere en nuwere teologieë van die Ou en Nuwe Testament laat blyk alreeds dat daar by samestellers van sodanige teologieë heelwat meningsverskille is oor wat die ordenende beginsel behoort te wees waarvolgens 'n teologie saamgestel moet word en gedefinieer kan word. Enkele voorbeelde sal die'saak duidelik maak. Jacob (1964: 11) gee die volgende definisie van 'n teologie van die Ou Testament: 'The theology of the Old Testament may be defined as the systematic account of the specific religious ideas which can be found throughout the Old Testament and which form its profound unity.' Westermann (1978: 6) sien die eenheidsbeginsel waarvolgens die Ou-Testamentiese getuienis in 'n teologie saamgevat kan word in 'dem durch das ganze Alte Testament hindurch konstant bleibende Reden von Gott'. Hy sê ook: 'Eine Theologie des Alten Testaments hat die Aufgabe zusammenzufassen und zusammenzusehen was das Alte Testament als ganzes in allen seinem Teilen van Gott sagt' (Westermann 1978: 5). Vriezen (1954:133) stel weer: 'De Oudetestamentisch theologie zoekt als theologisch wetenskap in het bijzonder het Openbaringselement in de Oudetestamentische prediking; zij moet dus met theologische maatstaven werken en bedoelt een eigen waardering van de Oudtestamentische verkondiging te geven op grond van haar Christelijke uitgangspunt.'

'n Mens vind dieselfde meningsverskil by die saamstel van teologieë van die Nuwe Testament. Kümmel (1972: 15) is van mening dat ' $n$ teologie van die Nuwe Testament saamgestel kan word na aanleiding van die getuienis van die hoofgetuies van die Nuwe Testament, naamlik die verkondiging van Jesus, die teologie van Paulus teen die agter- 
grond van die oergemeente en die Christusboodskap van die Johannesevangelie. Hy noem hierdie drie getuienisse vorme van verkondiging en glo dat daar 'n grondliggende eenheid in al drie vorme van verkondiging lê van waaruit 'n teologie van die Nuwe Testament ontvou kan word. Richardson (1961: 9) sê dat hy onder 'n Nuwe Testament teologie verstaan: ' ... the framing of an hypothesis concerning the content and character of the faith of the apostolic Church, and the testing of this hypothesis in the light of all available techniques of New Testament scholarship, historical, critical, literary, philological, archaeological and so on.'

Dit is voorwaar 'n wye verskeidenheid van opvattings wat 'n sistematiese teoloog teëkom wanneer hy hom na die Bybelse teologie wend vir'n gesprek - en dan het ons nog nie eens die probleem aangeraak of daar dalk sprake is van meer as een teologie in die Ou en Nuwe Testament en of sodanige teologieë in 'n geheel saamgesnoer kan word en nog talle ander vrae nie. ' $n$ Mens sou kon vra of Bybelse teologie vanuit so ' $n$ verskeidenheid van opvattings iets van betekenis vir die Sistematiese teologie te sê het. Ek is van mening dat die Bybelse teologie nie alleen iets van belang nie, maar wel iets van wesenlike belang, vir die Sistematiese teologie te sê het; iets wat die Sistematiese teologie nodig het vir ' $n$ behoorlike beoefening daarvan. Die verskil van mening oor wat 'n teologie van die Ou en Nuwe Testament is en hoe dit opgebou word, werk geensins verwarrend in op 'n Sistematiese teoloog nie, aangesien dit na my mening meer 'n metodologiese kwessie is as wat dit die inhoud van ' $n$ Bybelse teologie wat vir die Dogmatiek van belang en bruikbaar is, raak. Die Sistematiese teologie se belang lê by die stof wat 'n Bybelse teologie as resultaat van die wetenskaplike werksaamhede van die Ou- en Nuwe-Testamentiese Wetenskap aan die Sistematiese teologie beskikbaar stel. Daarom sou ek as eerste versoek aan die Bybelse teologie vra: Moenie ophou met die arbeid aan die uitbou van Bybelse teologie nie, al sou daar heelwat vakwetenskaplike probleme wees wat om antwoorde vra. Sonder 'n Bybelse teologie sou ook die Sistematiese teologie baie armer wees.

Die ontstaan van Bybelse teologieë is ' $n$ uitvloeisel van die Kerkhervorming. Die Reformatore het die tradisie as 'n bron van die kerklike teologie verwerp en daarteenoor die beginsel sola Scriptura gestel. Die verwerping van die tradisie, soos Boers (1979: 17) dit stel, het ingehou dat die Christelike teologie nie langer sy eie gedagtes as sonder meer identies met die Bybelse gedagtes kan beskou nie. Die Bybel kon nie soos vroeër sonder meer beskou word as 'n bron van materiaal vir die 
eie gedagtes nie. Die teologie moes probeer om tot die gedagtes van die Bybelskrywers self deur te dring, eerder as om van die eie gedagtes uit te gaan. Eers daarna moes die gedagtes van die Bybelskrywers in terme van die huidige lewe van die kerk verklaar word. Dit is wat ' $n$ man soos byvoorbeeld Calvyn in sy Institusie probeer doen het. Uitgaande van die sola Scriptura-beginsel het hy sy Intitusie niks anders probeer laat wees as ' $n$ sistematiese aanbieding van die gedagtes van die Bybelskrywers nie.

Die eerste Bybelse 'teologieë' het egter ongelukkig nie as sistematiese aanbieding van die gedagtes van die Bybelskrywers ontstaan nie (Boers 1979: 20), maar het binne die Lutherse ortodoksie tot stand gekom as versamelings van aanhalings uit die Bybel waarin tekste uit die Ou en Nuwe Testament na willekeur naas mekaar en aanvullend tot mekaar gebruik is. Die veronderstelling was dat die verskillende leerstellinge en dogmas van die Lutherse ortodoksie in die tekste uitgedruk is. Die veronderstelling waarop die 'teologieë' gebaseer is, was dat die leerstellinge van die Hervorming in elk geval op die Bybel gegrond is en dat hierdie versamelings van tekste ' $n$ middel was om te verseker dat hierdie leerstellings op die Bybel gegrondves bly. Daarbenewens moes dit ook die Bybelse aard en gesag van die leerstellinge bevestig.

Die skrywers van hierdie teologieë het werklik probeer om getrou aan die Reformatoriese beginsel van sola Scriptura te bly, maar ongelukkig het dit in die praktyk nie so uitgewerk nie, want waar die Reformatore in hulle denke uitgegaan het van die Bybel as basis, het daar nou 'n sisteem van dogmatiese teologie binne die Protestantisme ontwikkel. Hiermee word bedoel: Die skrywers van hierdie teologieë het na die Bybel vanuit die gesigspunt van 'n dogmatiese sisteem gaan kyk en het van daaruit probeer om die Bybel tot die basis van dié dogmatiese sisteem te maak. Dit was in der waarheid 'n direkte ommekeer van die benadering van die Kerkhervormers. Hierdie teologieë was niks anders as die dogmatiese teologie van die Lutherse ortodoksie nie. Dit is net deur middel van tekste uitgedruk. Wat dus in werklikheid gebeur het, is dat die dogmatiese teologie die basis van die Bybelse teologie en die Bybeltekste die struktuur daarvan gaan vorm het, in plaas van omgekeerd, soos by die Reformatore.

Vanuit hierdie les uit die geskiedenis is dit 'n redelike versoek aan opstellers van Bybelse teologieë om nie in dieselfde valstrik te trap deur teologieë daar te stel wat deur leerstellige oorwegings gekleur is of een of ander vorm van dogmatiese sisteem as vooroordeel het nie. Deur wel só 'n soort teologie aan te bied, word sowel die Bybelse teologie as die 
Dogmatiek 'n onguns aangedoen - die Bybelse teologie deurdat dit die gevaar loop om sy resultate in ' $n$ sisteem te dwing wat die Bybel dalk vertroebel en verwring, en die Dogmatiek deurdat dit met Bybelse stof moet werk wat vooraf in 'n sekere rigting gekleur is sodat die Dogmatiek gevolglik nie sy eie sisteem op suiwer gronde kan bou nie. Die Nuwe-Testamentiese teologie van Alan Richardson (1961) is ' $n$ voorbeeld van 'n teologie waar dogmatiese oorweginge ingesluip het. Die definisie wat Richardson van 'n Nuwe Testament teologie gee en wat ons alreeds vroeër aangehaal het, maak duidelik dat hy in hierdie rigting dink. Hoewel sy werk 'n baie bruikbare en deeglik wetenskaplike werk is, is dit ook duidelik dat die dogmatiese vooroordeel waarmee hy dit geskryf het, tot nadeel van die werk strek, aangesien dit sy Nuwe Testament teologie die aanskyn van ' $n$ voorlopige inleiding tot die Dogmatiek gee.

Die ontwikkeling van sake met betrekking tot die ontstaan van Bybelse teologieë, soos hierbo met betrekking tot dié binne die Lutherse ortodoksie geskets, het geleidelik die besef laat ontstaan dat, ten spyte van goeie bedoelings, die toepassing van die Reformatoriese beginsel sola Scriptura nie tot sy reg gekom het nie, deurdat 'n dogmatiese sisteem eerder as die Skrif die grondslag gevorm het. Behalwe dat die sola Scriptura-beginsel net mooi omgekeerd, as wat die oorspronklike bedoeling van die Reformatore was, toegepas is, is daar ook' $n$ metodologiese probleem met die sola Scriptura-prinsipe ervaar (Ebeling 1960: 74; kyk ook Boers 1979: 18). Sola Scriptura het ingehou dat die teologie nie net inhoudelik op die Bybel gegrond moet word nie, maar ook formeel wat die denkkategorieë betref van waaruit die teologie bedryf is. Die formele denkkategorieë wat uit die folosofie oorgeneem is, is nie meer as dienslik beskou nie. Die Bybel self moes die denkkategorieë vir 'n konsekwente toepassing van die beginsel van sola Scriptura verskaf. Dit het ' $n$ ernstige probleem vir die Reformatoriese teologie geskep, want die eie aard van die Bybel is nie sodanig dat dit hierdie formele algemene denkkategorieë waarmee 'n teologiese sisteem gebou word, kan voorsien nie. Die feitelike situasie is dat die formele denkkategorieë van die filosofie nie opgeoffer kon word nie, hoewel dit vreemd aan die Bybel was. Dit is vanuit hierdie gevoel van onbehaaglikheid rondom die toepassing van die beginsel van sola Scriptura dat die aandrang op 'n Bybelse teologie gekom het.

Johan Philip Gabler wie se werksaamhede rondom die einde van die agtiende eeu plaasgevind het, word algemeen beskou as die persoon wat met sy verhelderende insigte Bybelse teologie 'n plek as afsonder- 
like dissipline los van dogmatiese teologie gegee het (kyk Boers 1979: 23-39). Gabler se werk in dié verband kan in terme van drie hoofonderskeidings gekarakteriseer word, naamlik tussen godsdiens en teologie, tussen Bybelse teologie en dogmatiese teologie en tussen Bybelse teologie in ' $n$ enger en 'n wyer sin. Gabler se doel met die onderskeidinge was om binne die raamwerk van die breëre en grotere teologiese onderneming te onderskei tussen die verskillende aspekte van die teologiese taak as geheel en om so ' $n$ afsonderlike dissipline te voorsien wat die onderskeie aspekte van sowel Bybelse teologie as dogmatiese teologie kan hanteer, die grense van dié dissiplines definieer en die interaksies tussen hulle aandui. Vir die doeleindes van ons studie is Gabler se onderskeiding tussen Bybelse teologie en dogmatiese teologie van belang. Sy hoofdoel met die onderskeiding was om die Bybel weer as die grondslag van die hele teologie gevestig te kry. Die uiteindelike doel was om 'n Bybels-gebaseerde dogmatiese teologie tot stand te bring. Gabler se oogmerk met Bybelse teologie was dat die Bybel die enigste basis vir alle teologie moet word en dat die Bybel ondersoek moet word deur 'n dissipline wat heeltemal onafhanklik van dogmatiese teologie staan. Hy wou gehad het dat die Bybel ondersoek word deur Bybelse teologie wat slegs ' $n$ verantwoordelikheid het teenoor die Bybelse materiaal. Gabler wou nie dogmatiese teologie uitskakel nie. Inderdaad was sy uiteindelike doel met Bybelse teologie om, soos hierbo vermeld, by die korrekte dogmatiese teologie uit te kom wat stewig gevestig sou wees op 'n Bybelse teologie, wat op sy beurt op 'n suiwer Bybelse basis sou rus. Gabler se onderskeiding hou dus 'n Bybelse teologie as dissipline in wat heeltemal van dogmatiese teologie los staan, maar wat tog op 'n dogmatiese teologie gerig is deurdat dit die sekondêre grondslag daarvan vorm; sekondêr in die sin dat die Bybel die primêre basis is.

Die bogenoemde onderskeidinge van Gabler kom in die gesprek tussen die Sistematiese teologie en die Bybelse teologie goed te pas. In die lig van Gabler se onderskeidinge kan die Sistematiese teologie van die Bybelse teologie verwag om in die eerste plek alleen verantwoordelik te wees aan die Bybelse stof waarmee dit werk, maar in die tweede plek - en dit is belangrik - om so beoefen te word dat dit 'n brug kan vorm tussen die eksegese en eksegetiese resultate van die Bybelwetenskappe aan die een kant en die Dogmatiek aan die ander kant. Ons het hier min of meer dieselfde op die oog as wat Vriezen (1953: 129-130) onder die begrip 'Ou-Testamentiese teologie' wil verstaan, naamlik dat dit die verbindingslid is tussen die 'dogmatiese' en die 'historiese' 
teologie. Dit wil sê, aldus Vriezen, dat dit die materiaal wat die Bybel lewer, soos ons dit ook in die lig van die geskiedenis leer verstaan, op so ' $n$ wyse byeenbring sodat die dogmatikus in sy dogmaties-sistematiese werk kan weet waarom dit werklik in die Bybel gaan.

Gabler se helderheid en die duidelikheid van sy onderskeidinge het egter met verloop van tyd verlore gegaan deur die eensydige beklemtoning van die onafhanklikheid van Bybelse teologie ten opsigte van Sistematiese teologie (Boers 1979: 25). Hierdie dwang tot onafhanklikheid het sekerlik voortgespruit uit 'n vrees vir die moontlikheid dat Bybelse teologie weer kan terugval in 'n voorafbepaaldheid deur die Sistematiese teologie. Hierdie onafhanklikheid van die Bybelse teologie het egter tot gevolg gehad dat dit sy skakelende en bemiddelende funksie tussen eksegese en dogmatiese teologie ingeboet het. (Gabler self sou die term Bybelse godsdiens in die plek van eksegese gebruik het, aangesien hy onder Bybelse godsdiens die direkte goddelike onderrig wat daar in die Bybel gevind word, verstaan.)

So ' $n$ totale onafhanklikheid van die Sistematiese teologie is nie sonder inherente gevare vir die Bybelse teologie nie. Die een gevaar is dat waar die Bybelse teologie net 'n doel op sigself geword het, die onderskeid in terme van dogmatiese teologie op die lang duur kan vervaag en dogmatiese belange onvermydelik ' $n$ vasstrapplek in Bybelse teologie kan verkry. Bybelse teologie moet sy gerigtheid op die Sistematiese teologie behou. Juis die besef dat sy doel nie in homself lê nie, maar dat sy doel daarin lê om 'n stewige Bybelse grondslag wat van ' $n$ dogmatiese voorafbepaaldheid los staan en waarop die Dogmatiek sy sisteem kan bou, weerhou hom van so 'n ongemerkte dogmatiserende tendens. Jacob (1963: 31) is reg as hy sê dat 'n Ou Testament (Bybelse) teologie nie sonder 'n relasie met die Dogmatiek is nie. Die regte verhouding waarin die Bybelse teologie steeds sy onafhanklikheid kan behou, is om homself aan die een kant in die Bybel vas te anker en aan die ander kant die hand na die Dogmatiek uit te strek. Dit is vir die Dogmatiek belangrik dat Bybelse teologie nie in afsondering beoefen sal word nie, maar sy gerigtheid op die Dogmatiek behou. Op dié manier sal Bybelse teologie nie net alleen sy eie funksie beter vervul en trou bly aan sy ware doel nie, maar ook die Dogmatiek help om sy eie taak beter uit te voer deur te doen wat Jacob (1963: 31) soos volg formuleer: ' $\ldots$ by supplying the raw material, biblical theology will remind dogmatics of its limits and will preserve it from falling into a subjectivism where the essential might be sacrificed to the accessory.' 
Met betrekking tot sy stof is die Bybelse teologie onafhanklik; met betrekking tot sy doel is dit op die Dogmatiek gerig.

Die obsessie om Bybelse teologie onafhanklik te hou, het ook onbedoelde nadelige gevolge gehad. Aan die een kant is Bybelse teologie so in afsondering beoefen dat daar baie weinig stof gelewer is wat vir die Sistematiese teoloog bruikbaar is. Aan die ander kant is daar die neiging by Bybelse teoloë om die hele teologiese taak vir hulleself op te eis en die Sistematiese teoloë op die kantlyn uit te skuif. Tegelykertyd is hiermee saam skerp kritiek gelewer op die Skrifgebruik van dogmatici, oor die metodes waarvolgens hulle die Dogmatiek struktureer ensovoorts. Daar is dan ook 'n merkbare verergerlikheid by Ou- en Nuwetestamentici as dit vir hulle lyk asof die dogmatici nie op hulle kritiek reageer nie. Die feit is egter dat hulle self in 'n groot mate hiervoor te blameer is, aangesien die Sistematiese teoloë so min stof waarop hulle kan reageer, ontvang het. Daar is so min van die nuutste eksegetiese bevindinge in Bybelse teologieë georden dat 'n dogmatikus nie werklik kan sê dat hy met 'n aangepaste Bybelse grondslag die Sistematiese teologie op sy beurt weer kan aanpas en indien nodig herstruktureer nie. ' $n$ Versoek aan die woordvoerders van die Bybelse teologie is om hulle kritiek teenoor dogmatici in ' $n$ baie groter mate met die nodige Bybelse stof aan te vul sodat die Dogmatiek op ' $n$ beter grondslag beoefen kan word.

Ebeling (1960: 72-74) wys daarop dat 'n swakheid in die ontwikkeling van die teologie van die Reformatore was dat hulle nie die verhouding tussen die sistematies-teologiese metode en die eksegese opgeklaar het nie. Die eksegese is in die latere gang van die Reformasie binne die grense wat reeds vantevore deur die Dogmatiek getrek is, beoefen. ' $n$ Spanning tussen eksegese en Bybelse teologie aan die een kant en die Sistematiese teologie aan die ander kant is dus vantevore alreeds uitgesluit. Die Sistematiese teologie was dus in werklikheid die sistematiese geheelontvouing van die Christelike leer wat normatief vir die eksegese was. Die Reformatore wou die leidende rol aan die eksegese gee, maar het tog geglo dat die sistematies-teologiese werkwyse en die eksegese onafskeidelik saamhoort. 'n Gevolg hiervan is die soort Dogmatiek-beoefening wat ' $n$ mens selfs vandag nog by sommige dogmatici kry en waarin die Skrifgebruik niks anders is as ' $n$ blote bevestiging van alreeds aanvaarde en gevestigde leerstellinge nie. Veel eerder moes die leerstellinge, na aanleiding van die bevindinge van die eksegese en Bybelse teologie, getoets, hersien en uitgebou word.

Bybelse teologie kan die Sistematiese teologie help deur vanuit sy 
gesigspunt lig op die vraag hoe die verhouding tussen die sistematiesteologiese metode en die eksegese die beste uitgespel kan word, te werp. Dalk kan Gabler se gedagtes ook hier verhelderend inwerk (kyk Boers 1979: 25). Gabler maak die onderskeid tussen godsdiens (Religion) en teologie. Hy veronderstel dat die Bybel nie teologie bevat nie, maar godsdiens. Onder godsdiens verstaan hy die goddelike onderrig wat in die Bybel voorkom. Godsdiens is die gewone eenvoudige manier van verstaan. Teologie is ' $n$ subtiele, hoogs verfynde manier van verstaan. As 'n wyse van verstaan staan die twee teenoor mekaar, maar teologie is tog veronderstel om op godsdiens gebou te wees. Gabler meen dat die teologieë en die ortodokse teologieë van vroeër bloot gefunksioneer het as uitdrukking van die bestaande leerstellings van die dogmatiese teologie. Hy redeneer dat as die Bybel die enigste basis van die teologie moet wees, dan moet dit deur 'n dissipline ondersoek word wat heeltemal onafhanklik van dogmatiese teologie is en wat slegs ' $n$ verantwoordelikheid het teenoor die Bybelse materiaal wat geïterpreteer word. Die laaste gedeelte van Gabler se gedagtegang, aldus Boers, is volledigheidshalwe gegee. Ons wil die aandag op Gabler se onderskeid tussen godsdiens en teologie vestig en vra of die verhouding tussen die eksegese en die sistematies-teologiese metode nie langs dié lyne, met 'n aanpassing vir moderne terme en insigte, gesien behoort te word nie.

Tans lê Bybelse teologie baie sterk klem op die diversiteit en die pluraliteit in die getuienis van die Bybel. Hierdie verskeidenheid word, soos dit vir my lyk, in die Ou Testament teologie vanweë die aard van die Ou Testament as 'n redelik vanselfsprekende saak aanvaar. Rowley (1956: 14 en 17) stel reeds byna dertig jaar gelede dat ons in die $\mathrm{Ou}$ Testament die optekening vind van ' $\mathrm{n}$ lang groeiproses. Die gevolg is dat daar nie 'n statiese eenheid in die Ou Testament gevind kan word nie. Idees en praktyke wat op een of ander stadium van die Ou-Testamentiese periode ontgroei geraak het, vervul dus wel in ' $n$ deel van die Ou Testament 'n bepaalde rol. 'n Ou Testament teologie moet volgens Rowley (1956: 17) deur 'n skerp historiese sin en deur die erkenning dat idees en praktyke van verskillende oorsprong en op verskillende vlakke van ontwikkeling binne die Ou Testament gevind word, gekenmerk word.

Dit is my indruk as Sistematiese teoloog dat hierdie diversiteit en pluriformiteit so skerp moontlik deur Nuwetestamentici belig word. Hefner (1966) stel aan die hand van die studies van die Nuwetestamentikus Ferdinand Hahn en die Outestamentikus Klaus Koch hoe Nuwe- 
Testamentiese studies die diversiteit van die Nuwe-Testamentiese getuienis sterk beklemtoon. Dit is beslis ' $n$ winspunt wat Bybelse teologie aan die Sistematiese teologie te bied het, naamlik om die Sistematiese teologie, wat geneig is om die Bybel vanuit 'n eenheidsvisie te benader, skerp van die diversiteit in die Bybel bewus te maak. Hierdie bewuswording sal die Sistematiese teoloog daarvan weerhou om Bybeltekste te maklik te harmoniseer en gelyk te skakel. Bybelse teologie kan nuwe insigte vir die Sistematiese teologie open deur aan die Sistematiese teologie die verskillende aspekte van hierdie diversiteit voor te hou, soos byvoorbeeld dié een wat deur Hefner (1966: 433) geformuleer word: 'Our only view of the earthly Jesus is, so to speak, through a kaleidoscope, and that kaleidoscope's refracting lense is the many coloured, many splendoured constellation of the early Christian Community's traditions of belief. We are completely reliant upon that community for the knowledge that is essential to our faith as Christians.'

Die diversiteit van die Bybelse getuienis wat die Bybelse teologie so sterk stel, het nie net ' $n$ positiewe waarde vir die Sistematiese teologie nie, maar kan ook negatief daarop inwerk, afhangende van hoe dit gestel en oorgedra word. Dit is ongelukkig so dat woordvoerders van die Bybelse teologie en veral die Nuwe Testament teologie dikwels die feit van diversiteit in die Bybelse getuienis op so ' $n$ manier aan Sistematiese teoloë stel dat hulle die diversiteit ervaar as 'n saak wat grens aan totale onsamehangendheid waarin die lê van enige verbande 'n saak van onmoontlikheid is. As dit al is wat 'n Sistematiese teoloog hoor, skep dit by hom die indruk dat Ou- en Nuwetestamentici in ' $n$ mindere of meerdere mate van mening is dat Sistematiese teologie ' $n$ uitgediende onderneming is, omdat dit in die lig van die diversiteit van die Bybelse getuienis in werklikheid nie beoefen kan word nie. Sistematiese teoloë hoor soms slegs die een kant van die saak wat Hefner (1966: 432) soos volg formuleer: 'Hahn and Koch remind us also that biblical scholarship today has no intention of smoothing out the diversities in the biblical witness.'

Dit is egter belangrik om daarop te let dat Hefner (1966: 432) die ander kant ook stel: 'Rather, the currents of biblical scholarship seem to be high-lighting these diversiteis and to attempt to forge a methodology that will not eliminate diversity so much as to come to terms with it and incorporating it in our present understandings.' Dit doen die Sistematiese teologie nie goed as dit nie ook hierdie ander keersy van die saak in ' $n$ sterker mate uit die mond van die Bybelse teologie hoor nie. Bybelse teologie moet by die ontwerp van ' $n$ Bybelse teologie iets 
van sy metodologiese worsteling rondom die diversiteitsproblematiek oordra. Indien die Sistematiese teologie meer hiervan hoor, sal dit op sy beurt gehelp word om tot ' $n$ beter begrip te kom van hoe om die diversiteit in 'n dogmatiese sisteem bruikbaar te maak en te integreer.

Dit het weer tyd geword dat Ou- en Nuwetestamentici meer moet werk op die moontlikheid om verbande en samehange te lê tussen die verskillende aspekte waarin die Bybelse getuienis tot ons kom en wat die korrekte wyse is om dié verbande te definieer. Sonder een of ander vorm van ' $n$ eenheidsvisie op die Bybelse getuienis is geen Sistematiese teologie, en ook geen Bybelse teologie, moontlik nie. Jacob (1964: 12-13) stel ten opsigte van Ou Testament Teologie dat dit nie prinsipieel moontlik is om daarvan te praat as daar nie a fortiori van die interne eenheid van die Ou Testament uitgegaan word nie. Die eenheid van die Bybel hoef nie so geïnterpreteer te word dat dit in stryd is met die diversiteit van die Bybelse getuienis nie. So byvoorbeeld praat Rowley (1956: 14) van die eenheid van groei in die Ou Testament. Die eenheid van die Ou Testament is nie 'n statiese eenheid nie, maar 'n eenheid waarin elke fase van groei oorweeg word in sy relasie tot die geheel, maar ook in sy uniekheid. Rowley (1956: 17) sê dat die eenheid nie bedink moet word as die eenheid van Judaïsme wat uit 'n proses voortgekom het waarin Judaïsme verskillende elemente in homself geïntegreer het nie, maar as die eenheid van die ontwikkeling van die besondere geloof van Israel. Rowley se gedagtes is maar net een voorbeeld van wat ons in gedagte het met die stelling dat die Bybelse teologie iets meer moet sê oor wat ons by gebrek aan beter woorde 'n 'prinsipe van eenheid' wil noem. Hiermee word bedoel dat Bybelse teologie moet ingaan op die beginsel van waaruit verbande en samehange binne die werklikheid van die diversiteit in die Bybelse getuienis gelê kan word.

So 'n onderneming lê nie buite die vermoë van die Bybelse teologie nie. Sekere basiese riglyne kan ten minste getrek word. In die verband deel ek Schooneberg (1975: 268) se siening: 'Toch blijft bijbelse theologie mogelijk. De grond van haar mogelijkheid ligt in de twee qualificaties de we Schillebeeckx aan de nieuwtestamentische Jezus-interpretasie hoorden geven: "pluralistisch en niettemin grondig één". Als samevattingen niet in het pluralisme verdrinken, maar daarin ongeforceerd de eenheid laten zien, als zij omgekeerd de eenheid niet vlak maken maar haar de pluraliteit doen oplichten, dan hebben wij een goede bybeltheologie."

Indien Ou- en Nuwetestamentici meer van hulle worsteling met 
hierdie vraagstuk deurgee, sal hulle die Sistematiese teoloë voor die volgende vrae skerper stel en hulle ook aanspoor om die uitdaging te aanvaar om vanuit die Sistematiese teologie ' $n$ antwoord te gee. Die vrae wat die Sistematiese teologie dan moet beantwoord en wat deur Hefner (1966: 434-436) geformuleer is, is:

1. Hoe gee ons rekenskap van die diversiteit wat ons binne die vroegste Christelike tradisies kry?

2. Hoe gee ons rekenskap van die kontinuiteit van die Christelike geloof binne die Christelike gemeenskap van die vroeë kerk? Hoe is dit met ander woorde dan dat die vroegste Christelike gemeenskap nie uitmekaar geval het nie, hoewel hulle tradisies tog so verskillend was?

3. Wat is die beste manier om die diverse - selfs moontlik teenstrydige besonderhede - van die vroeë kerk se tradisies te verenig?

'n Sistematiese teoloog moet voortdurend kennis neem van die resultate van die eksegese en staan onder ' $n$ verpligting om in sy opbou van 'n Sistematiese teologie hierdie eksegetiese resultate in te werk. Soos Barr (1974: 12) aantoon, is dit 'n saak waarin die Sistematiese teoloog versigtig te werk moet gaan, want daar is altyd die moontlikheid dat die eksegetiese resultate hersien kan word en selfs baie radikaal hersien kan word. 'n Sistematiese teoloog kan nie anders as om hom op die eksegetiese resultate te verlaat nie, maar hy moet tog sy Sistematiese teologie op so 'n sterk fondament uitbou dat dit nie uitgelewer word aan verbygaande giere en modes in die eksegese nie. In hierdie opsig kan die Bybelse teologie die dogmatikus op ' $n$ terrein te hulp kom waarin die dogmatikus nie so goed onderlê is nie. Ou- en Nuwetestamentici kan in die proses van die deurgee van eksegentiese resultate binne ' $n$ Bybels-teologiese raamwerk in 'n tipe voorafsifting aandui watter resultate op vaste bene staan en watter nie. ' $n$ Bybelse teologie as 'n 'samevattende' werk (Schoonenberg 1975: 266) kan 'n Sistematiese teoloog help om nie oorhaastig 'n sisteem opgedetailleerde eksegetiese studies te bou nie.

Die gesprek van die Sistematiese teologie met die Bybelse teologie het alreeds groot waarde as dit ons daarvan bewus maak dat nòg die Sistematiese teologie nòg die Bybelse teologie in isolasie beoefen kan word nie. 'n Beoefening van die eie vak in isolasie lei op die ou end tot een of ander skeeftrekking - of dit nou kom van die Bybelse teologie in die rigting van ' $n$ dogmatiserende tendens en of dit van die Dogmatiek kom wat in 'n sisteem groter gesag as in die Bybelse stof vind. Daar 
moet so ' $n$ wisselwerking tussen Bybelse teologie en Sistematiese teologie wees dat ons bewus bly van die eenheid van die teologiese dissiplines - nie 'n eenheid met opheffing van die verskeidenheid nie, maar 'n eenheid in wisselwerking (Ebeling 1960: 89).

\section{Literatuurverwysings}

BARR, J 1974. Some Old Testament aspects of Berkhof's Christelijk geloof in weerwoord, in Festschrift voor prof $\mathrm{H}$ Berkhof. Nijkerk.

BOERS, H 1979. What is New Testament theology? The rise of criticism and the problem of a theology of the New Testament. Philadelphia: Fortress.

EBELING, G 1960. Was heisst 'Biblische Theologie'?, in Wort und Glaube, Vol 1. Tübingen: Mohr.

HEFNER, P 1966. Recent developments in form criticism and their significance for systematic theology. $I R$.

JACOB, E 1964. Theology of the Old Testament. 3rd ed. London: Hodder \& Stoughton.

KÜMMEL, WG 1972. Die Theologie des Neuen Testaments nach seinen Hauptzeugen JesusPaulus-Johannes. 2. Aufl. Göttingen: Vandenhoeck \& Ruprecht.

RICHARDSON, A 1961. An introduction to the theology of the New Testament. 2nd ed. London: SCM.

ROWLEY, HH 1956. The faith of Israel: Aspects of Old Testament thought. London: SCM.

SCHOONENBERG, P 1975. Schillebeeckx en de exegese: Enige gedachten by lesus het verhaal van een levende. TTH.

VRIEZEN, Th C 1954. Hoofdlijnen der theologie van het Oude Testament. 2de dr. Wageningen: Veenman \& Zonen.

WESTERMANN, C 1978. Theologie des Alten Testaments in Grundzügen. Göttingen: Vandenhoeck \& Ruprecht. (Das Alte Testament Deutsch-Ergänzungsreihe 6.) 